\title{
Effectiveness of Two Different Methods of Health Education on Diabetic Patients' Knowledge about their Disease in the Urban Primary Health Care Units in Ismailia City
}

\author{
Sobhy A. Sobhy ${ }^{1}$, Youssef W. Malak ${ }^{1}$, Hamdy A. Sleem ${ }^{2}$, \\ Mayada M. Ghweeba ${ }^{1^{*}}$
}

Departments of ${ }^{1}$ Community Medicine, ${ }^{2}$ Internal Medicine, Faculty of Medicine, Suez Canal University, Egypt

\begin{abstract}
Background: Diabetes education has been considered as an important part of the clinical management of diabetic patients. A large body of literature suggests that patient education improves diabetes knowledge of diabetic patients. Aim of this study was to identify the effectiveness of power point and the small group discussion health education methods on diabetic patients' knowledge about their disease. Patients and Methods: This intervention study was conducted on 170 diabetic patients attending El-Salam PHC unit who were randomly allocated in the two intervention groups. After health education programs, data were collected by using a diabetic patients' questionnaire before and after the health education programs for each group of the study to evaluate the effect of each method on participants' knowledge. Results: The results showed a significant difference between participants' knowledge of the two groups from $4.64 \pm 2.627$ tog.75 \pm 2.203 in the PPT group and from $4.68 \pm 2.601$ to11.88 \pm 2.456 in the small group discussion group. Conclusion: all participants' knowledge showed an improvement after the two methods especially in the small group discussion method showed marked improvement in all domains of participants' knowledge about their disease.
\end{abstract}

Keywords: diabetic education, PPT, small group discussion

\section{Introduction}

Health education is the profession of educating people about health $^{(1)}$, it's a process by which individuals and groups of people learn to behave in a manner conducive to the promotion, maintenance or restoration of health ${ }^{(2)}$. Diabetic patients' education has been considered as an important part of the clinical management of individuals with diabetes. It is not only teaches prevention and basic health knowledge but also conditions ideas that re-shape everyday habits of people with unhealthy lifestyles in developing countries $^{(3)}$. This type of conditioning affects the immediate recipients of such education as well as future generations will benefit from an improved and properly cultivated ideas about health that will eventually be ingrained with widely spread health education. Communication in relation to health education involves different modes like lectures, group or panel discussions, symposia, poster or exhibit presentation etc. Every

*Corresponding Author: mayadghweeb@yahoo.com 
individual mode of health education has its own merits, drawbacks as well as their own sphere of effectiveness ${ }^{(4)}$.

Selecting appropriate health education method is the first and foremost about utilizing processes that will help achieve desired program goals and objectives and should be a part of a planning process that reflects both theoretical and ethical elements ${ }^{(5)}$. The connection between objectives and the presentation methods requires the health educator to asses the relevant information and skills that are part of the presentation. Well written objectives make it clear to both the target audience $^{(6)}$.

Selecting the appropriate health education method includes the following concepts for the target group: (1) Understanding the needs of the target population. (2) Developing meaningful objectives and goals to guide selection of method. (3) Identify the appropriate presentation methods. (4) Gather resources to aid program implementation of methods. (5) Sequence methods for a safe environment $^{(7)}$.

Effective presentation is a skill that all health educators can and should improve. It takes a great deal of practice and experience, but the benefit outweighs the cost. Steps for conducting effective presentation are: (1) Prepare for the presentation setting. (2) Understand different presentation settings. (3) Use effective skills to make a presentation. (4)Reduce distracting mannerisms ${ }^{(8)}$. Health education Program evaluation is a systematic way to improve and account for public health actions by involving procedures that are useful, feasible, ethical, and accurate. Public health professionals use framework guides for program evaluation which is a practical, non prescriptive tool, designed to summarize and organize essential elements of program evaluation.
This framework will allow an understanding of each program's context and will improve how program evaluations are conceived and conducted $^{(9)}$.

Diabetes is a global problem with devastating human, social and economic impact. Average prevalence of diabetes in Egypt as a whole for people above the age of 20 was $10 \%{ }^{(10)}$. The prediction that developing countries would show a significant increase in diabetes due to population growth, ageing, unhealthy diets, obesity and sedentary life styles.

Since the 1970s, teaching people in groups has been seen as an effective intervention for diabetes education. The process of education has evolved over time. Patient education is now a well accepted and essential part of practice for all health professionals; it is a cornerstone of diabetes self-management, and it is central to achieving improved outcomes of care. Several reviews of educational interventions compare the effectiveness of group and individual education in different situations ${ }^{(10)}$. The aim of this study was to compare the effect of health education method power-point (PPT) method versus the small group discussion method on diabetic patients' knowledge about their disease.

\section{Methods}

This intervention study was conducted in El Salam primary health care unit in Ismailia city. The study population was diabetic patients with type 2 diabetes who attend the PHC unit for their regular routine follow up. The study sample included 170 participants with 85 participants in each group. They were randomly allocated into the intervention groups: group A (using the power point presentation method) or group $B$ (the group discussion method of health education). The data collection tool 
was an interview questionnaire included the socio-demographic data and diabetes history of the participants, then application of the diabetic patients' knowledge questionnaire for each participant before and after the intervention to evaluate their baseline level of knowledge and to assess the effect of each health education program on participants' knowledge. The program passed through three phases: planning, implementation, and evaluation phases. Planning phase included preparation of the health education program materials included the PPT with camtasia aid records, booklets and posters and Preparation of the health education cession place in the $\mathrm{PHC}$ and conduction of an orientation cession to the team in the PHC about the program. Implementation phase included application of the health education programs.

The two programs were represented in three cessions (through their routine visits) with at least two weeks interval with maximum number of 10 participants in each cession to ensure the delivery of the message. The three sessions of the programs included the following topics: (1) the nature of diabetes disease. (2) Diabetes complication and its management. (3) Diabetes acute and chronic complications. Then followed by the evaluation phase: with the post-intervention evaluation questionnaire.

\section{Statistical Analysis}

Data was analyzed using the statistical program statistical package for social science version 16 software (SPSS 16). Data was presentated using numerical and tabular presentation methods. We used Chisquare test for the qualitative data and $\mathrm{t}$ test for the quantitative data.

\section{Ethical Considerations}

Informed consent was taken from the patients who participated in the study. The patient had the right to withdraw from the study at any time with neither jeopardizing the right of the patient to be treated nor affecting the relationship between the patient and the care provider in the primary health care unit. Confidentiality of all data and results of all the study population was ensured.

\section{Results}

The total number of diabetic patients who participated and completed this study were 170 participates with 85 participants in each group. The results of this study were represented in the following parts: (1) socio-demographic data of the participants. (2) Diabetic history of the participants. (3)Participant's Knowledge questionnaire about diabetes that was measured before and after the health education programs. Table 1 showed the distribution of participant's sociodemographic data included gender, age, educational level, occupation, and marital status. In table 2 showed the distribution of the participants regarding their medical history of diabetes (duration of diabetes, complication, regularity of follow up). No significant difference was found between both groups regarding personal or medical history of diabetes $(p>0.05)$. The diabetic knowledge questionnaire measures the participants' knowledge about: 1) the nature of diabetes, 2) diabetes management, 3) diabetes complications. Table (3) showed comparison between participants' knowledge about the nature of diabetes before and after the health education programs. All participants' answer in this section showed an improvement in their knowledge with variable degrees after the health education programs. The most unknown question among the PPT group was about value of the different methods of testing blood glucose (Q 2). 
Table 1: Distribution of the participants according to their personal characters

\begin{tabular}{|c|c|c|c|}
\hline Characters & $\begin{array}{l}\text { PPT group } \\
\text { No }(\%)\end{array}$ & $\begin{array}{c}\text { Group discussion } \\
\text { No }(\%)\end{array}$ & $P$ value \\
\hline \multicolumn{4}{|l|}{ Age } \\
\hline$-30-$ & $3(3.5 \%)$ & $5(5 \cdot 9 \%)$ & 0.908 \\
\hline$-40-$ & $29(34.2 \%)$ & $19(22.4 \%)$ & \\
\hline$-50-60$ & $24(28.2 \%)$ & $29(34.1 \%)$ & \\
\hline$-\geq 60$ & $29(34.1 \%)$ & $32(37.6 \%)$ & \\
\hline- Mean \pm SD & $54.35 \pm 10.234$ & $56.29 \pm 11.438$ & \\
\hline Gender & & & 0.530 \\
\hline - Male & $31(36 \%)$ & $36(32 \%)$ & \\
\hline - Female & $54(64 \%)$ & $58(68 \%)$ & \\
\hline Occupation & & & 0.742 \\
\hline - Working & $35(41.2 \%)$ & $39(45.9 \%)$ & \\
\hline - Not working & $40(47.1 \%)$ & $35(41.2 \%)$ & \\
\hline - Retired & $10(11.7 \%)$ & $11(12.9 \%)$ & \\
\hline Level of education & & & 0.350 \\
\hline - Illiterate & $10(12 \%)$ & $15(18 \%)$ & \\
\hline$-R \& w$ & $40(47 \%)$ & $39(46 \%)$ & \\
\hline - Middle & $24(28 \%)$ & $24(28 \%)$ & \\
\hline - High & $11(13 \%)$ & $7(8 \%)$ & \\
\hline Marital status & & & 0.286 \\
\hline - Single & $11(12.9 \%)$ & $8(9.4 \%)$ & \\
\hline - Married & $49(57.7 \%)$ & $13(15 \cdot 3 \%)$ & \\
\hline - Divorced & $4(4.7 \%)$ & $7(8.2 \%)$ & \\
\hline - Widow & $21(24.7 \%)$ & $57(67.1 \%)$ & \\
\hline
\end{tabular}

The percent of patients who know the answer was (nine patients, $10.6 \%$ ), and after the health education program the percentage of the patients who know the answer raised to (40 patients, $47 \%$ ). While In the group of group discussion (question 2), also showed the lowest percent of knowledge of the patients which was (4 patients, $4.7 \%$ ) before the health education, and after the health education program which became (57 patients, 67\%). Table (4) showed an improvement in participants' knowledge about diabetes complication after the health education programs especially in-group discussion participants. Participant's knowledge about diabetes management showed a statistically significant difference after the intervention (Table 5). Table (6) showed the mean of the total score of both groups were also nearly the same before the health education in both groups (4.64 \pm 2.627 for the PPT group and $4.68 \pm 2.601$ for the group discussion group) and the difference between both groups were statistically non-significant. However, the difference between both groups was statistically significant after the health education program $(9.75 \pm 2.203$ for the PPT group and $11.88 \pm 2.456$ for the group discussion group). 
Table 2: Distribution of the participants according to their medical history of diabetes

\begin{tabular}{|l|llc|}
\hline Characters & $\begin{array}{l}\text { PPT group } \\
\mathrm{n}=85\end{array}$ & $\begin{array}{l}\text { Group discussion } \\
\mathrm{n}=85\end{array}$ & $\begin{array}{c}\mathrm{P} \\
\text { value }\end{array}$ \\
\hline Duration of diabetes (Yrs) & & & \\
$-1-$ & $12(14 \%)$ & $15(18 \%)$ & 0.194 \\
$-5-$ & $53(62 \%)$ & $47(55 \%)$ & \\
$-10-15$ & $20(24 \%)$ & $19(22 \%)$ & \\
$->15$ & $0(0 \%)$ & $4(5 \%)$ & 0.034 \\
Complications & & & \\
- Hypertension & $26(30.6 \%)$ & $20(23.5 \%)$ & \\
- Eye diseases & $8(9.4 \%)$ & $10(11.8 \%)$ & \\
- D. neuropathy & $9(1.1 \%)$ & $7(8.2 \%)$ & \\
- D. nephropathy & $6(7.1 \%)$ & $12(14.1 \%)$ & \\
- Heart diseases & $4(4.7 \%)$ & $6(7.1 \%)$ & \\
- Others & $7(8.2 \%)$ & $11(12.9 \%)$ & \\
Regularity of follow up: & & & \\
- Regular & $59(69 \%)$ & $62(73 \%)$ & \\
- Irregular & $26(31 \%)$ & $23(27 \%)$ & \\
\hline
\end{tabular}

\section{Discussion}

Diabetes mellitus is a chronic disease that requires a great attention and cooperation from patient and the health team to control the disease and to limit and prevent development of complication. This can be done through medical treatment and health education of the patients. The purpose of the present study was to evaluate the effectiveness of two different presentations methods of health education (power point presentation method and, group discussion presentation method) on diabetic patients' knowledge about their disease. One-hundred and seventy diabetic patients were participated in this study with eighty-five patients in each group (PPT and group discussion group).

Regarding to the analysis of the participants' knowledge about their diabetes through the diabetes knowledge questionnaire, the analysis showed that: there is a marked improvement of participants' knowledge after the health education programs intervention in both groups with variable degree of improvement. This is an important finding in the light of recent work identifying the significance of keeping the diabetes control in the prevention or regression of existing diabetes complications $^{(11)}$.

In the analysis of the diabetic questionnaire results, the improvement of the patients' knowledge about the nature of diabetes was more marked in the group 2 (group discussion group) from the baseline mean score of $1.441 \pm 1.101$ to 4.223 $\pm 1.442(p=0.0001)$. In addition, the PPT group showed a significant improvement in patients' knowledge with mean score from $1.494 \pm 1.315$ to $3.329 \pm 1.2677$. Comparing the post intervention, score results showed a significant difference between the two groups. 
Table 3: Comparison between participants' knowledge about diabetes nature before and after the health education program

\begin{tabular}{|c|c|c|c|c|c|c|}
\hline Question & & $\begin{array}{l}\text { PPT } \\
\text { presentation } \\
n=85\end{array}$ & $\begin{array}{l}\text { Group } \\
\text { discussion } \\
\mathrm{n}=85\end{array}$ & $\begin{array}{l}\text { Total } \\
\mathrm{N}=170\end{array}$ & $\chi^{2}$ & $\mathrm{p}$ value \\
\hline \multirow{2}{*}{$\begin{array}{l}\text { Q 1. knowledge } \\
\text { about diabetes as a } \\
\text { chronic disease }\end{array}$} & B & $28(32.9)$ & $21(24.7)$ & $49(28.8)$ & 1.405 & 0.236 \\
\hline & A & $52(61.1)$ & $51(60)$ & $103(60.5)$ & 2.068 & 0.356 \\
\hline \multirow{2}{*}{$\begin{array}{l}\text { Q 2. methods of } \\
\text { testing blood } \\
\text { glucose level }\end{array}$} & $B$ & $9(10.6)$ & $4(4.7)$ & $13(7.6)$ & 2.083 & 0.353 \\
\hline & $A$ & $40(47)$ & $57(67)$ & $97(57)$ & 7.168 & $0.028 * *$ \\
\hline \multirow{2}{*}{$\begin{array}{l}\text { Q 6. causes that } \\
\text { may rise blood } \\
\text { glucose level }\end{array}$} & B & $19(22.3)$ & $19(22.3)$ & $38(22.4)$ & 5.867 & 0.053 \\
\hline & A & $52(61.2)$ & $66(77.7)$ & $118(69.5)$ & 6.323 & $0.042^{* *}$ \\
\hline \multirow{2}{*}{$\begin{array}{l}\text { Q 7. symptoms of } \\
\text { diabetes. }\end{array}$} & $B$ & $19(22.3)$ & $24(28.2)$ & $43(25 \cdot 3)$ & 5.815 & 0.055 \\
\hline & A & $46(54.1)$ & 79 (92.9) & $125(73.5)$ & 33.426 & $0.001^{* *}$ \\
\hline \multirow{2}{*}{$\begin{array}{l}\text { Q 8. how can food } \\
\text { and stress affect } \\
\text { blood glucose level }\end{array}$} & $B$ & $26(30.6)$ & $26(30.6)$ & $52(30.6)$ & 0.001 & 1.000 \\
\hline & $A$ & $47(55.3)$ & $56(65.9)$ & $103(60.6)$ & 2.117 & 0.347 \\
\hline \multirow{2}{*}{$\begin{array}{l}\text { Q10. normal blood } \\
\text { glucose level }\end{array}$} & B & $26(30.6)$ & $29(34.1)$ & $55(32.4)$ & 1.316 & 0.919 \\
\hline & A & $45(52.9)$ & $50(58.8)$ & $95(55.9)$ & 1.879 & 0.391 \\
\hline
\end{tabular}

Data are presented as No. of participants who answered the question right (\%);** =statistically significant $(p<0.05) ; B=$ before; $A=$ after

This suggests that the method of health education experiences poses a greater challenge to effective health education. This cleared with the secondary analysis of data collected for a study on the effect of education on knowledge, self management behaviors, and self-efficacy of eighty patients with type 2 diabetes. The health education was delivered by the researchers using a question based patient centered approach which consisted of answering participants' questions about diabetes and its' care ${ }^{(12)}$. The total mean score of the participants before the health education was $(20.0 \pm 4.0)$ for the intervention group, and $(4.0 \pm 4.3)$ for the control group with a non-statistically significant $t$ test $(p=0.538)$ while after the health education programs the total mean score of the participants was $(21.9 \pm 3.2)$ for the in- tervention group and $(19.4 \pm 4.4)$ for the control group with a statistically significant difference between the study groups $(p=0.006)^{(13)}$. Based on the results of this study, the following recommendations were pro-posed: 1) Many diabetic patients in type 2 lack the basic knowledge about their disease. Improving these issues through the health education through their regular routine visits will help improving diabetes control. 2) Developing effective health education programs using the advantage of the group discussion method as an effectiveness method of health education in short term evaluation. Ideal programs aim to improve the diabetic patients' knowledge about diabetes, should also directed to the patients' knowledge and practice towards their disease $^{(14)}$. 
Table 4: Comparison between participants' knowledge about diabetes complications before and after the health education programs

\begin{tabular}{|c|c|c|c|c|c|c|}
\hline Question & & $\begin{array}{l}\text { PPT } \\
\text { presentation } \\
n=85\end{array}$ & $\begin{array}{l}\text { Group } \\
\text { discussion } \\
\mathrm{n}=85\end{array}$ & $\begin{array}{l}\text { Total } \\
n=170\end{array}$ & $\chi^{2}$ & $p$ value \\
\hline $\begin{array}{l}\text { Q 4: what are diabetes chronic } \\
\text { complications }\end{array}$ & $\begin{array}{l}B \\
A\end{array}$ & $\begin{array}{l}15(17.6) \\
39(45.8)\end{array}$ & $\begin{array}{l}15(17.6) \\
59(69.4)\end{array}$ & $\begin{array}{l}30(17.6) \\
98(57.6)\end{array}$ & $\begin{array}{l}4.464 \\
10.195\end{array}$ & $\begin{array}{l}0.107 \\
0.006 * *\end{array}$ \\
\hline $\begin{array}{l}\text { Q 12: fatty substance in food } \\
\text { linked to heart diseases. }\end{array}$ & $\begin{array}{l}B \\
A\end{array}$ & $\begin{array}{l}24(28.2) \\
49(57.6)\end{array}$ & $\begin{array}{l}30(35 \cdot 3) \\
52(61.2)\end{array}$ & $\begin{array}{l}54(31.8) \\
101(59.4)\end{array}$ & $\begin{array}{l}5.833 \\
0.237\end{array}$ & $\begin{array}{l}0.888 \\
0.054\end{array}$ \\
\hline $\begin{array}{l}\text { Q 15: how to management } \\
\text { acute hyperglycemia }\end{array}$ & $\begin{array}{l}B \\
A\end{array}$ & $\begin{array}{l}19(22.4) \\
46(54.1)\end{array}$ & $\begin{array}{l}12(14.1) \\
48(56.5)\end{array}$ & $\begin{array}{l}31(18.2) \\
94(55 \cdot 3)\end{array}$ & $\begin{array}{l}1.936 \\
1.691\end{array}$ & $\begin{array}{l}0.380 \\
0.429\end{array}$ \\
\hline $\begin{array}{l}\text { Q 16: effect of acute respirato- } \\
\text { ry infection on blood glucose }\end{array}$ & $\begin{array}{l}B \\
A\end{array}$ & $\begin{array}{l}49(57.6) \\
28(32.9)\end{array}$ & $\begin{array}{l}31(36.5) \\
45(52.9)\end{array}$ & $\begin{array}{l}80(47.0) \\
59(34.7)\end{array}$ & $\begin{array}{l}0.406 \\
0.216\end{array}$ & $\begin{array}{l}0.816 \\
0.878\end{array}$ \\
\hline $\begin{array}{l}\text { Q 17: action you do with acute } \\
\text { respiratory infection }\end{array}$ & $\begin{array}{l}B \\
A\end{array}$ & $\begin{array}{l}35(41.2) \\
39(45.9)\end{array}$ & $\begin{array}{l}27(31.8) \\
50(58.8)\end{array}$ & $\begin{array}{l}62(36.5) \\
89(52.4)\end{array}$ & $\begin{array}{l}2.399 \\
3.508\end{array}$ & $\begin{array}{l}0.231 \\
0.173\end{array}$ \\
\hline $\begin{array}{l}\text { Q18: hyperglycemia rising } \\
\text { chance of acute infection }\end{array}$ & $\begin{array}{l}B \\
A\end{array}$ & $\begin{array}{l}35(41.2) \\
55(64.7)\end{array}$ & $\begin{array}{l}34(40) \\
61(71.8)\end{array}$ & $\begin{array}{l}69(40.6) \\
116(68.2)\end{array}$ & $\begin{array}{l}1.010 \\
2.590\end{array}$ & $\begin{array}{l}0.603 \\
0.274\end{array}$ \\
\hline
\end{tabular}

Data are presented as No. of participants who answered the question right (\%); ** =statistically significant $(p<0.05)$; $B=$ before; $A=$ after

Table 5: Comparison between participants' knowledge about diabetes management before and after the health education program

\begin{tabular}{|c|c|c|c|c|c|c|}
\hline Question & & $\begin{array}{l}\text { PPT } \\
\text { presentation } \\
n=85\end{array}$ & $\begin{array}{l}\text { Group dis- } \\
\text { cussion } \\
\mathrm{n}=85\end{array}$ & $\begin{array}{l}\text { Total } \\
\mathrm{N}=170\end{array}$ & $X^{2}$ & $p$ value \\
\hline \multirow{2}{*}{$\begin{array}{l}\text { Q 3: food only can manage pa- } \\
\text { tients with DM-2 }\end{array}$} & $B$ & $14(16.4)$ & $9(10.60)$ & $23(13 \cdot 5)$ & 1.596 & 0.450 \\
\hline & $A$ & $56(65.8)$ & $58(68.2)$ & $114(67)$ & 1.053 & 0.591 \\
\hline \multirow{2}{*}{$\begin{array}{l}\text { Q 5: effect of insulin without } \\
\text { ordinary meal on blood glucose }\end{array}$} & B & $28(32.9)$ & $21(24.7)$ & $49(28.8)$ & 2.048 & 0.236 \\
\hline & $A$ & $43(50.5)$ & $65(76.4)$ & $108(71.2)$ & 12.481 & $0.002 * *$ \\
\hline \multirow{2}{*}{$\begin{array}{l}\text { Q 9: importance of food control } \\
+ \text { tablet as a treatment of } \mathrm{DM}-2\end{array}$} & B & $15(17.6)$ & $17(20)$ & $32(18.8)$ & 0.169 & 0.919 \\
\hline & A & $45(52.9)$ & $56(68.2)$ & $101(59.4)$ & 3.444 & 0.179 \\
\hline \multirow{2}{*}{$\begin{array}{l}\text { Q 11: components of diabetic } \\
\text { patients' healthy food. }\end{array}$} & B & $22(25.9)$ & $23(27.1)$ & $45(26.3)$ & 0.30 & 0.862 \\
\hline & $A$ & $38(44.7)$ & $57(67.1)$ & $95(55.9)$ & 8.708 & $0.013^{* *}$ \\
\hline \multirow{2}{*}{$\begin{array}{l}\text { Q 13: effect of regular exercise } \\
\text { on blood glucose in DM-2. }\end{array}$} & B & $17(20)$ & $24(28.2)$ & $41(24.1)$ & 17.053 & 0.064 \\
\hline & A & $41(48.2)$ & $46(54.1)$ & $87(51.2)$ & 1.441 & 0.487 \\
\hline \multirow[t]{2}{*}{ Q14: foot care steps. } & B & $47(55 \cdot 3)$ & $31(36.5)$ & $78(45.9)$ & 6.065 & $0.014 * *$ \\
\hline & A & $44(51.8)$ & $39(45.9)$ & $83(48.8)$ & 4.063 & 0.131 \\
\hline
\end{tabular}

Data are presented as No. of participants who answered the question right (\%); ** =statistically significant ( $<<0.05)$; $\mathrm{B}=$ before; $\mathrm{A}=$ after; $\mathrm{DM}-2=$ diabetes mellitus type 2 
Table 6: Comparing the mean score of diabetes knowledge questionnaire before and after the health education programs:

\begin{tabular}{|l|lllll|}
\hline $\begin{array}{l}\text { Health } \\
\text { education } \\
\text { topics }\end{array}$ & & $\begin{array}{l}\text { Before health } \\
\text { education }\end{array}$ & $\begin{array}{l}\text { After health } \\
\text { education }\end{array}$ & T test & P value \\
\hline Diabetes nature & $\mathrm{B}$ & $1.494 \pm 1.315$ & $1.441 \pm 1.101$ & 0.287 & 0.774 \\
& $\mathrm{~A}$ & $3.329 \pm 1.2667$ & $4.223 \pm 1.442$ & 4.294 & 0.0001 \\
Diabetes & $\mathrm{B}$ & $1.294 \pm 1.1004$ & $1.447 \pm 1.1903$ & 0.870 & 0.386 \\
management & $\mathrm{A}$ & $3.235 \pm 1.231$ & $3.871 \pm 1.270$ & 3.311 & 0.001 \\
Diabetes & $\mathrm{B}$ & $1.82 \pm 1.465$ & $1.75 \pm 1.353$ & 0.326 & 0.745 \\
complication & $\mathrm{A}$ & $3.25 \pm 1.224$ & $3.71 \pm 1.526$ & 2.162 & 0.032 \\
Total score & $\mathrm{B}$ & $4.64 \pm 2.627$ & $4.68 \pm 2.601$ & 0.117 & 0.907 \\
& $\mathrm{~A}$ & $9.75 \pm 2.203$ & $11.88 \pm 2.456$ & 5.95 & 0.001 \\
\hline
\end{tabular}

Data are presented as mean $\pm \mathrm{SD}$; $\mathrm{B}=$ before; $\mathrm{A}=$ after

\section{References}

1. Donatelle R. Health: The basics. 8th edition. San Francisco, CA: Pearson Education, (2009).

2. Werner RT. Wilson J. Are health education conferences effective? An evaluation of knowledge gain in a three-day institute. Health Educ 12(4):22-24.

3. Bundy D and Guya HL. Schools for health education and the school-age child. Health today 1996; 12(8): 1-16.

4. Patterson SM. Vitello EM. Key Influences Shaping Health Education: Progress toward Accreditation. Health Edu Monograph Series, 2006; 23(1): 14-19.

5. Montgomery SB. The Health Belief Model in Understanding Compliance with Preventive Recommendations for AIDS: How Useful? AIDS Edu \& Prevent 2000; 1(4):303-323.

6. Atkinson M, MacLaren NK. Mechanism of disease: the pathogenesis of insulin dependent diabetes mellitus. $N$ Engl J Med 2001; 24:1014-1018.

7. World Health Organization. International diabetic prediction report true facts about diabetes, (2009). On http://http:// www.who.int/diabetes/facts/en/index.html

8. Richard A. The Use of Significant Reduction Rates to Evaluate Health Education
Methods for Pregnant Smokers: Health Educ Behav. 1999; 26 (5):648-662

9. Bartholomew LK, Parcel GS, Kok G, Gottlieb NH. Planning Health Promotion Programs. (2nd ed.) San Francisco,CA: Jossey-Bass. 2006. 71:377-380

10. Armitage CJ.Is there utility in the transtheoretical model? $\mathrm{Br} J$ Health Psychol 2009;14(2):195-210.

11. Hawthorne K. Effect of culturally appropriate health education on glycemic control and knowledge of diabetes in Brit Pakist women health edu res, 2001; 16 (3) :373-381.

12. Windsor RA, Bailey WC, Richards JM Jr, Manzella B, Soong SJ, Brooks M. Evaluation of the efficacy and cost effectiveness of health education methods to increase medication adherence among adults with asthma. Am J Public Health. 1990; 80(12):1519-1521.

13. Erskine P, Daly H, Idris I, Scott A: Patient preference and metabolic outcomes after starting insulin in groups compared with one-to-one specialist nurse teaching. Diabetes, 2002; 51 (2):77-82.

14. Houts PS, Doak CC, Doak LG, Loscalzo MJ. The role of pictures in improving health communication: a review of research on attention, comprehension, recall, and adherence. Patient Educ Couns. 2006; 61(2):173-190. 